Early Warning Systems and Monitoring Solutions

\title{
Monitoring Water Quality in the Northern Adriatic Sea
}

\author{
Irena Ciglenečki, Jelena Dautović, Milivoj Kuzmić \\ Institue Ruđer Bošković Division for Marine and Environmental Research, Bijenička 54, 10000 Zagreb, Croatia \\ doi: https://doi.org/10.21467/abstracts.93.57
}

\begin{abstract}
Dissolved organic matter (DOM), is one of the largest pools of organic carbon in the biosphere and is equivalent in magnitude to terrestrially fixed carbon. In the 300 - $800 \mathrm{~nm}$ wavelength range, DOM in surface waters can be divided into transparent and light absorbing groups. The absorbing-fraction, chromophoric dissolved organic matter (CDOM), historically referred to as gelbstoff, humic matter, or yellow substances, is the primary absorber of sunlight and a major factor that determines the optical properties of natural waters and directly affects both the availability and the spectral quality of light. Recently, importance of OM especially its chromophoric fraction in natural waters has increased due to; intensive remote sensing of ocean color related to organic carbon cycling; remote sensing of chlorophyll as an indicator of primary productivity and the potential interference in its measurement by CDOM; and carbon cycling in coastal waters.

DOM concentrations in natural waters can be assessed from the concentration of dissolved organic carbon (DOC) which makes approximately $90 \%$ of the organic carbon in the oceans and/or from the spectral properties of CDOM. While the absorption of light by CDOM affects both the inherent and apparent optical properties of seawater, optical methods, including remote sensing, may be successfully applied to study the distribution of CDOM in the ocean as well as in coastal and inland waters. Within the Croatian Science Foundation projects MARRES and EcoRENA surface waters' dissolved organic matter concentration were measured in the northern Adriatic during spring and summer season in 2017 and 2018 by standard high temperature catalytic oxidation method (HTCO). Measurements indicate different water quality in spring and summer seasons in both studied years.

These results, although extremely valuable, are inevitably of limited spatial and temporal extent. Satellitebased monitoring, with unavoidable tradeoffs, provides repeated, synoptic measurements over large areas, and is the natural next step. However, satellite sensors cannot detect DOC directly because not all the organic carbon is chromophoric. CDOM and DOC relationship can be successfully established, as demonstrated e.g. in Mannino et al (2008). The approach can be applied even in optically shallow waters if additional requirements are satisfied (Ciglenečki et al, 2020). Ocean color remote sensing, with properly validated and tested algorithms, offers valuable cost-effective tool for monitoring sub-basins like the northern Adriatic, and timely detection of possibly detrimental changes that might develop there.
\end{abstract}

Acknowledgement. Financial support of Croatian Science Foundation projects MARRES and EcoRENAis highly acknowledged.

\section{References}

Mannino, A., Russ, M.E., Hooker, S.B. 2008. Algorithm development and validation for satellite-derived distributions of DOC and CDOM in the U.S. Middle Atlantic Bight, J. Geophys. Res., 113, C07051, doi: 10.1029/ 2007JC004493.

Ciglenečki, I., Čanković, M., Kuzmić, M., Pagano, M. 2020. Accumulation of organic matter in a mesotidal Mediterranean lagoon (Boughrara, Tunisia). In review.

(C) 2020 Copyright held by the author(s). Published by AIJR Publisher in "Abstracts of The Second Eurasian RISK-2020 Conference and Symposium" April 12- 19, 2020, Tbilisi, Georgia. Jointly organized by AMIR Technical Services LLC, Georgian Technical University, Institute of Geography (Kazakhstan) and Russian Institute of Petroleum Geology and Geophysics.

Aij. DOI: $10.21467 /$ abstracts.93 